\title{
SUN TRACKING SOLAR STILL WITH EXTERNAL REFLECTOR AFFECTING PRODUCTIVITY OF DESALINATED WATER
}

\author{
El-Sheikh, I. H.*
}

\section{ABSTRACT}

The main objective of the present study was to improve the productivity of a traditional single-slope solar still using an external reflector and moving the solar still to track the sunrays from sunrise to sunset. A single slope solar still was designed, installed and tested at the Agricultural Engineering Department, Faculty of Agriculture, Suez Canal University, Ismailia Governorate, Egypt (latitude angle of $30.62^{\circ} \mathrm{N}$, Longitude angle of $32.27^{\circ} \mathrm{E}$, and mean altitude above the sea level of $5 \mathrm{~m}$ ). The basin of solar still is rectangular in shape, and made of galvanized iron sheet. The gross dimensions of the basin are $1.30 \mathrm{~m}$ long, $0.80 \mathrm{~m}$ wide and 0.10 $m$ deep, with a net upper surface area of $1.04 \mathrm{~m}^{2}$. It is painted with matt black paint to absorb the maximum possible amount of solar radiation incident on it. In the sides of the basin, $70 \mathrm{~mm}$ of foam insulation is placed to reduce the heat losses. The solar still is covered with glass sheet $3 \mathrm{~mm}$ thick and inclined by a tilt angle of $31^{\circ}$. Three different configurations are examined; stationary non-tracking solar still without reflector, sun tracking still without reflector, and sun tracking still with external reflector. The obtained results indicated that, the productivity of tracking solar still with reflector was greater than the productivity of the other two solar stills by about $129 \%$ and $81 \%$, respectively.

\section{INTRODUCTION}

The supply of drinking water is one of the major problems in developing countries. Clean water is a basic human necessity, and without water the life will be impossible. Nowadays the pollution in rivers and lakes by industrial effluents and sewage disposal resulted in scarcity of fresh water in many big cities around the world.

*Associate Prof. of Agric. Eng. Dep., Fac. of Agric., Suez Canal Univ., 41522 Ismailia, Egypt. 
It is known that only $3 \%$ of water on planet earth is fresh where only $1 \%$ is available for humanity to use and the rest is polar ice (Abdallah and Badran, 2008). Single slope solar stills are one of the solar devices which can be used for fresh water production. They are considered as one of the cheapest solutions for purifying saline/brackish water and suitable for the Middle East and Africa due to their low cost and easily constructing and maintenance (Goosen et al., 2000). Many attempts have been made to increase the productivity of distillate of a basin type still, such as reducing bottom loss coefficient, reducing water depth, using external and internal condensers, using back wall with cotton cloth, use of dye, use of charcoal, condensing cover cooling, using reflector and so on (Tiwari et al., 2003). Among these modifications, adding internal and/or external reflectors can be useful and inexpensive one to increase the solar radiation incident on the basin liner as well as the distillate productivity of basin type still.

A1-Hayek and Badran (2004) experimentally examined two different basin type stills, the single-slope one with reflector on the whole inner surface, and the double-slope one without reflector. They found that, the single-slope still with reflector was about $20 \%$ more productive than the double-slope still without reflector. E1-Swify and Metias (2002) performed outdoor experiments with two different basin type stills, one is an ordinary single-slope still with a back wall of glass plate, and another is a single-slope still whose inner side walls and outer surface of the back glass wall were covered by highly reflecting materials. They reported that, the distillate productivities of the still with reflector were higher by $83 \%$ and $22 \%$ as compared with the ordinary still without reflector during winter and summer seasons, respectively. E1-Bahi and Inan (1999) examined the thermal performance of solar still consisted of a basin liner, parallel glass cover, external reflector, and external condenser integrated to behind the still. The external reflector was used to increase the solar radiation incident on the glass cover and at the same to provide a shadow area for condenser. They indicated that an external reflector can provide and maintain higher reflectivity than an internal one since there is no condensation on the external reflector surface causing a decrease in reflectivity. 
Sun tracking systems were used by some researchers to enhance the distillation yield or power production. Ibrahim (1996) conducted experimental investigation on a collector consisting of six parabolic troughs with trackers. Kalogirou (1997) described a tracking system which can be used with single-axis solar concentrating systems as an enhancer. Khalifa and Al-Mutwalli (1998) performed an experimental study to investigate the effect of using two axes sun tracking system on the thermal performance of compound parabolic concentrators CPC. The tracking of CPC collector showed a better performance with an increase in the collected energy of up to $75 \%$ as compared with an identical fixed collector.

A solar pond (SP) is a stable pool of salt water in which the water salinity increases in the middle layer from its top to the bottom with a gradient that prevents convective mixing in temperature. Heat is passively collected and stored in the lower convective zone because the middle layer is a non-convective zone (Arjunan et al., 2009). Most commercial multi-stage flash (MSF) units operate with a top brine temperature of 90$110^{\circ} \mathrm{C}$, heated by steam while the solar pond operates in the range of 30$95^{\circ} \mathrm{C}$. Therefore, in solar pond assisted multi-stage flash (MSF) systems, the first stage of MSF heat exchangers is changed to a liquid-liquid heat exchanger instead of steam-liquid heat exchanger (Micale et al., 2009). Since a solar pond is a solar collector and storage in one, it overcomes the intermittent nature of solar energy. However, the solar pond has to be oversized for winter conditions, necessitating some of the surplus summer heat to be wasted. On the other hand, waste heat energy from other sources (gas turbine, for example) may be used during periods of insufficient sunshine (Agha, 2009). These kinds of hybrid solar pond systems could store extra waste heat energy, such as from gas turbine exhaust during peak times to lower the fresh water production cost and the solar pond size (Tiwari et al., 2003; Drawish and Alsairafi, 2004; Kalogirou, 2005; Li et al., 2013).

\section{MATERIALS AND METHODS}

\section{Experimental setup}

A single slope solar still is designed, constructed and examined at the Agricultural Engineering Department, Faculty of Agriculture, Suez Canal 
University, Ismailia Governorate, Egypt (latitude angle of $30.62^{\circ} \mathrm{N}$, Longitude angle of $32.27^{\circ} \mathrm{E}$, and mean altitude above the sea level of $5 \mathrm{~m})$. The geometric characteristics of single slope solar still are as follows: width, $0.80 \mathrm{~m}$, length, $1.30 \mathrm{~m}$, still rafter angle, $31^{\circ}$, basin depth, $0.10 \mathrm{~m}$, basin surface area, $1.04 \mathrm{~m}^{2}$ as demonstrated in Fig. (1). The basin of solar still is rectangular in shape, and made of galvanized iron sheet. It is painted by red-lead primer then by matt-type black paint in order to maximize the absorbed solar radiation. To reduce the reflection of solar radiation and reduce heat losses by convection, a clear glass cover $3 \mathrm{~mm}$ thick is placed and inclined by a tilt angle of $31^{\circ}$ to transmit the maximum possible of solar radiation flux incident on it. Otherwise, with this inclined angle $\left(31^{\circ}\right)$ condensation will run down the underneath of glass cover into the trough rather than dropping from the cover into the basin. Experimental results showed that a solar still with glass cover plate of $3 \mathrm{~mm}$ thick gave $16.5 \%$ more productivity than the cover with glass cover of $6 \mathrm{~mm}$ thick (Murugavel et al., 2008). Glass cover has been sealed with silicon rubber which plays an important role to promote efficient operation of condensation as it can accommodate the expansion and contraction between dissimilar materials.

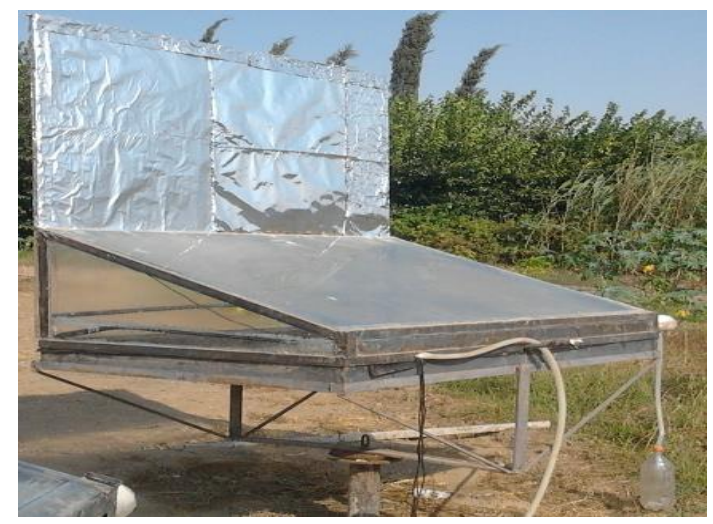

Fig. (1): Single slope solar still

The bottom frame is constructed of wood and insulated by a $2 \mathrm{~cm}$ thick of rock wool $\left(\mathrm{k}=0.0346 \mathrm{Wm}^{-1} \mathrm{~K}^{-1}\right)$ to reduce the heat lose. The outside walls are insulated with $7 \mathrm{~cm}$ thick foam $\left(\mathrm{k}=0.04 \mathrm{Wm}^{-1} \mathrm{~K}^{-1}\right)$ as shown in Fig. (2). The reflector which extends from the back side of the still is rectangular in shape, and made of plywood $15 \mathrm{~mm}$ thick. The 
gross dimensions of the reflector are $1.53 \mathrm{~m}$ long and $1.10 \mathrm{~m}$ wide, with a net face area of $1.683 \mathrm{~m}^{2}$. It is coated with aluminum foil as a reflective surface to maximize the reflected solar radiation. Therefore, the basin of solar still receives and absorbs three components of solar radiation (beam, diffuse, and reflectance solar radiation) that are transmitted through the glass cover. The solar energy absorbed at the base is largely transferred to the water in the still and a small fraction of it lost to the ambient by conduction through the base. To collect the distilled water from the solar still a trough is placed along the bottom side of the glass cover. The distilled water is continuously collected in a plastic vessel located outside the still and then measures by a graduated cylinder. The system has the capability to collect distillates from three sides of the still (i.e. the north, south and east sides). An inlet pipe is also fixed at the rear wall of the still for feeding brackish water as shown in Fig. (2).

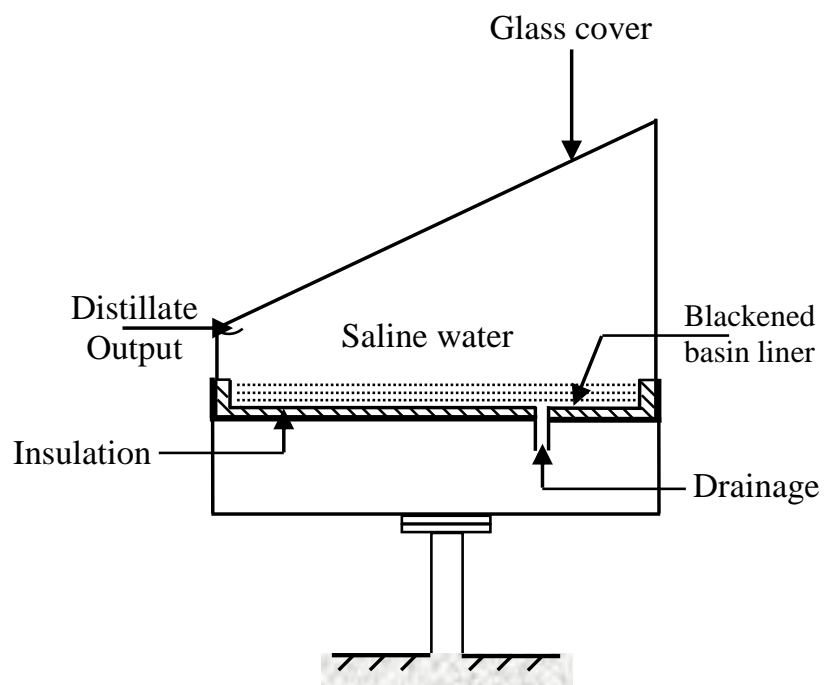

Fig. (2): Schematic diagram of experiment setup

\section{Measurements and data acquisition}

Different measuring devices were employed during the experimental work to measure intensity of solar radiation and temperatures. A Solar cell has dimensions of $75 \times 75 \mathrm{~mm}$ (Kemo, 139, German made) was connected to a digital multimeter (M3800, China) to measure the solar radiation flux incident on the solar still according to Mujahid and 
Alamoud (1988). A previously calibration was carried out against an American made apply Pyranometer before the experimental work was executed. The short circuit reading obtained from the cell was converted into $\mathrm{W} / \mathrm{m}^{2}$ according to Duffie and Beckman (2006). Five thermocouples (Type-k) connected to digital thermometer with a range from 0 to $150^{\circ} \mathrm{C}$ with accuracy of $\pm 0.1^{\circ} \mathrm{C}$ were functioned to measure the temperatures of various components of the solar still systems (ambient air temperature, $\mathrm{T}_{\mathrm{a}}$, basin water temperature, $\mathrm{T}_{\mathrm{w}}$, still vapour temperature, $T_{v}$, inside glass temperature, $T_{g i}$, and outside glass temperature, $T_{g o}$ ). The distillate output was recorded with the help of a measuring cylinder. The hourly variation of solar intensity, water, glass, ambient temperatures and hourly output of solar still were recorded.

\section{Methods}

In operation of the solar still, solar radiation was transmitted through the glass cover and absorbed by the saline water and the bottom of basin. The sensible heat absorbed by saline water was used to evaporate it and transferred to glass as water vapour where it was condensed on the under side of the glass cover (water vapour condenses in a film on inside surface that is at temperature below the dew-point temperature of the inside moist air). Another part of the heat from water was transferred to glass cover by free convection using air and remaining part by radiation. The glass cover transferred the heat to atmosphere by convection and radiation. Some heat energy is accumulated in the solar still in the form of sensible heat of the still and water. Some heat energy may be lost due to leakage of water vapour and water from the still. Condensate water was flowed by gravity into the collection trough at the lower edges of the tilted glass cover (glass cover was at sufficient slope $\left(31^{\circ}\right)$, therefore, surface tension of the water was caused it to flow into the trough without dropping back into the basin). Plastic container was used for collecting the distilled water coming out from the solar still. Saline water (30000 ppm) was used as feed. Experimental work was carried out on successive days during August month of 2013 (from 9 to 28), the experiments started from 9:00 am in the morning to 7:00 pm afternoon. Three configurations are examined, namely stationary non-tracking still without 
reflector, sun tracking still without reflector and sun tracking still with external reflector.

\section{Thermal efficiency of the solar still}

The thermal efficiency of a solar still is defined as the ratio of the rate of heat transfer $\left(\mathrm{q}_{\mathrm{ev}}\right)$ in the still by evaporation-condensation $\left(\mathrm{Wm}^{-2}\right)$ to the solar radiation $(\mathrm{R})$ on the still $\left(\mathrm{Wm}^{-2}\right)$. It can be calculated by the following equation (ASHRAE, 2005 ; Duffie and Beckman, 2006):

$$
\eta_{\mathrm{vol}}=\frac{q_{\mathrm{ew}}}{\mathrm{R}}
$$

This equation is usually integrated over some extended period (e.g, day or month) to indicate long-term performance. But, in practical there is some loss of product fresh water back into the basin of still (by dripping from the glass cover to leakage from collecting troughs), less product would be available than is indicated by the above equation. Therefore, the thermal efficiency of the solar still from the experimental measurements (volumetric thermal efficiency) which represents the productivity of fresh water; is mainly computed using the following equation (ASHRAE, 2005 ; Duffie and Beckman, 2006):

$$
\eta_{\text {vol }}=\frac{m_{p} h_{f g}}{3.6 A_{b} R}
$$

Where, $m_{p}$, is the rate at which distillate of fresh water is produced from the still in $\mathrm{kg} \mathrm{s}^{-1}, \mathrm{~h}_{\mathrm{fg}}$, is the latent heat of vaporization in $\mathrm{kJ} \mathrm{kg}^{-1}, \mathrm{~A}_{\mathrm{b}}$, is the surface area of basin in $\mathrm{m}^{2}$, and $\mathrm{R}$, is the solar radiation flux incident on the basin in $\mathrm{W} \mathrm{m}^{-2}$.

\section{RESULTS AND DISCUSSION}

For the duration of the experimental work, the three different configurations of solar still (stationary non-tracking, tracking without reflector, tracking with external reflector) were operated satisfactorily without malfunction. Various variables such as ambient air temperature $\left(\mathrm{T}_{\mathrm{a}}\right)$, glass cover temperature $\left(\mathrm{T}_{\mathrm{g}}\right)$, still vapour temperature, $\left(\mathrm{T}_{\mathrm{v}}\right)$, basin water temperature $\left(\mathrm{T}_{\mathrm{w}}\right)$, intensity of solar radiation $(\mathrm{R})$ and productivity of distilled water were hourly measured. Hourly variation of the global solar radiation, measured during the experimental period is plotted in Fig. 
(3). The intensity of solar radiation was gradually increased from sunrise till reached the maximum value at 14:00 h., then it gradually decreased until approached the minimum value prior to sunset. The maximum solar radiation recorded at that time for stationary non-tracking, tracking without reflector and tracking with reflector, respectively, was 997, 1040 and $1090 \mathrm{~W} / \mathrm{m}^{2}$. It can be seen that, the intensity of solar radiation on the tracking solar still with reflector was higher than that on the stationary non-tracking and tracking without reflector for most of the time, except only at noon. The highest difference between tracking solar still with reflector and stationary non-tracking occurred in the early morning (33\%) and late afternoon (40\%). This variation is due to the sun's rays are mainly vertical on the tracking solar still most of the time (Abdallah and Badran, 2008). This means at all times from sunrise to sunset, the rays of the sun are perpendicular to the surface, and consequently the angle of incidence equal zero at all times.

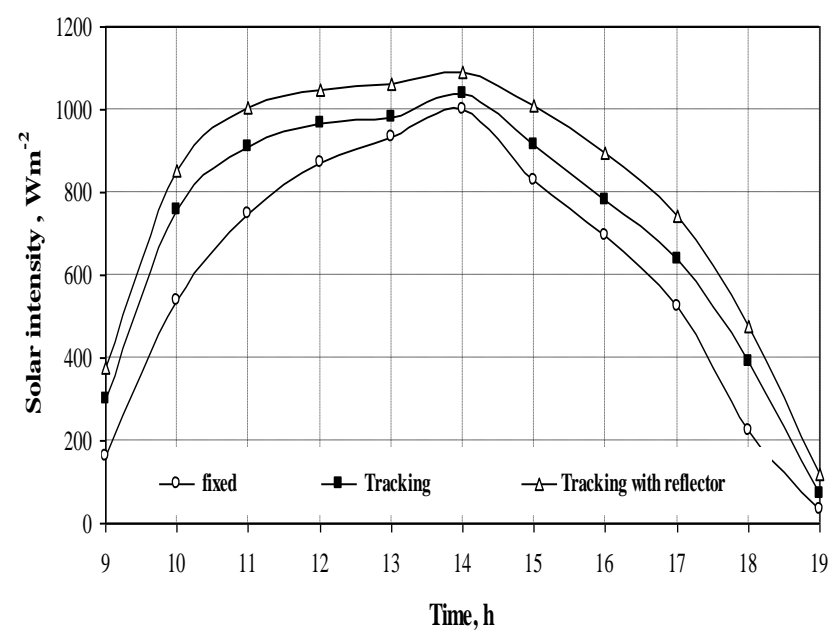

Fig. (3): Hourly average solar radiation intensity on the glass covers for stationary non-tracking, tracking without reflector, and tracking with reflector as a function of solar time.

Fig. (4) show the measured values of hourly variation of saline water temperature. It can clearly be seen that, an increase in the saline water temperatures occurred (from $35.5^{\circ} \mathrm{C}, 36.0^{\circ} \mathrm{C}$ and $36.3^{\circ} \mathrm{C}$, respectively) till it reached the maximum values $\left(67.1^{\circ} \mathrm{C}, 73.9^{\circ} \mathrm{C}\right.$ and $79.9^{\circ} \mathrm{C}$, 
respectively) in the afternoon (at $14.00 \mathrm{hr}$ ) due to the absorbed solar radiation exceed the losses to the surrounding. After $14.00 \mathrm{hr}$, saline water temperature decreased because the heat energy losses from the solar stills which became larger than the absorbed solar radiation. It also observed that the basin temperature get closer to the saline water temperature due to the continuous contact between them which led to heat equilibrium.

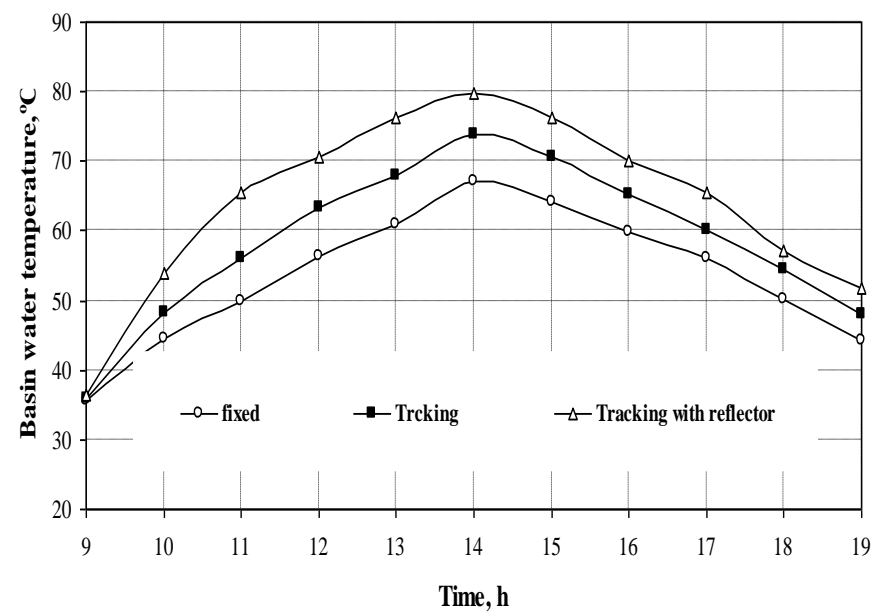

Fig. (4): Hourly average of saline water temperature for stationary non-tracking, tracking without reflector, and tracking with reflector as a function of solar time.

It can be noticed from Fig. (5), that the inner glass cover temperature was usually lower than that of the basin water temperature, except in the early morning when the difference between them was very small. As the glass cover temperature is much lower than the basin water temperature, it caused condensation of vapour on the inside surface area of the glass. In the early morning hours (8-9 am), the glass temperature was closest to the water and vapour temperatures resulting in small productivity due to the small heat energy absorbed by the water at these times. The difference in temperature between water and inner glass throughout the day for the three different configurations (stationary non-tracking, tracking without reflector, and tracking with reflector) is plotted in Fig. (6). It is clear that during early morning glass cover encountered the solar 
radiation first and its temperature rose very fast as compared with the rising in water temperature, and as a result the difference becomes negative. These differences remains negative till water temperature exceeded glass temperature. The maximum positive difference occurred at 15:00 $\mathrm{h}$ after that the difference decreases till the sunset.

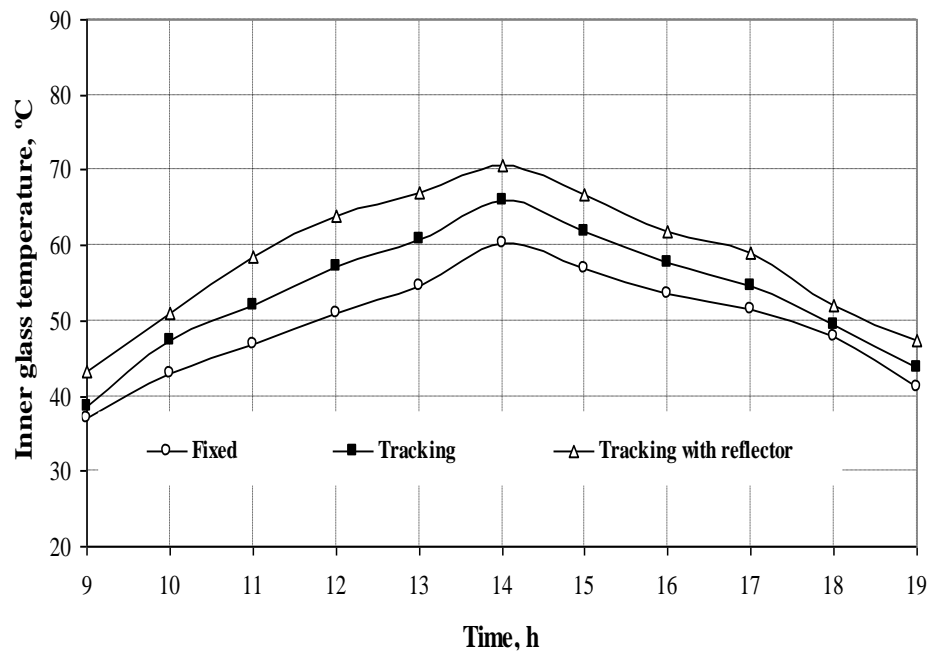

Fig. (5): Hourly variation temperature of inner glass for stationary non-tracking, tracking without reflector, and tracking with reflector as a function of solar time.

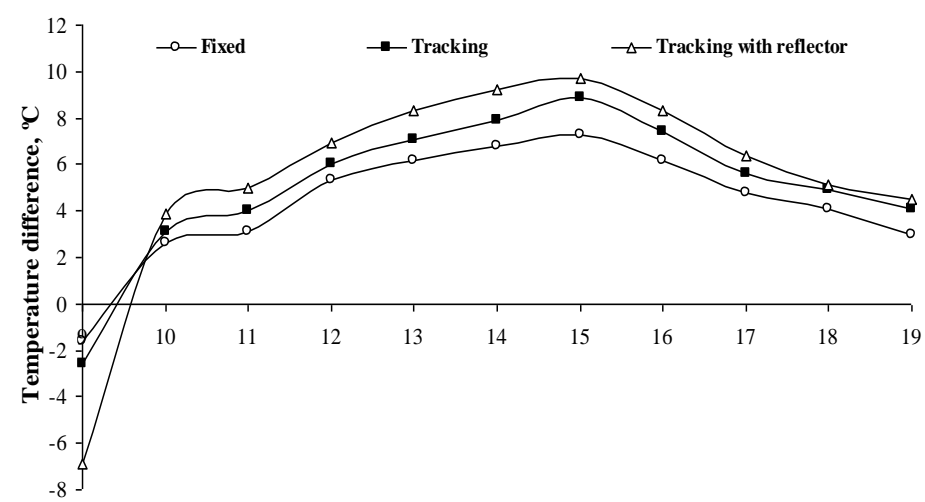

Time, h

Fig. (6): Hourly average temperature difference of saline water and inner glass cover for stationary non-tracking, tracking without reflector, and tracking with reflector as a function of solar time. 
As the intensity of the solar radiation inside the still for the three different configurations was increased, the productivity of fresh water increased due to the increase in heat energy gained for saline water vaporization inside the stills. The productivity rate of fresh water varied as time passes from early morning till late afternoon as shown in Fig. (7). It can be seen that, the productivity of fresh water for the three different configurations gradually increased from early morning until reached the maximum values (390, 700 and $860 \mathrm{ml} / \mathrm{hr}$, respectively) in the afternoon (at 15.00 hr) then they decreased till approached the minimum values (120.4, 145.6 , and $289.8 \mathrm{ml} / \mathrm{hr}$ ) just prior to sunset. The saline water temperature can be considered as one of the parameters that has a direct effect on the productivity of fresh water.

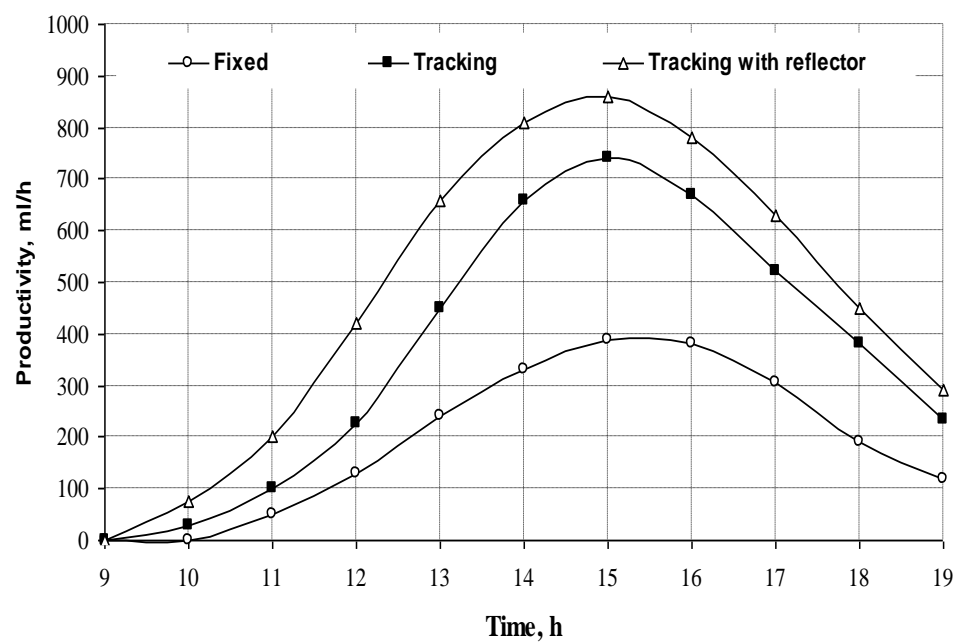

Fig. (7): Volumetric production rate for stationary non-tracking, tracking without reflector, and tracking with reflector as a function of solar time.

The solar still volumetric thermal efficiency is considered as the most important parameter that affects productivity of fresh water. The hourly average volumetric thermal efficiencies for the three different configurations are plotted in Fig. (8). The volumetric thermal efficiencies for the three different configurations increase with time until reaching the maximum value in the later afternoon. In the morning the temperature of saline water is low therefore it needs high energy to change its phase 
from saturated liquid to saturated vapour phase. The results show that temperature and required heat are inversely proportional. In the afternoon the temperature of water reaches the maximum so it needs less heat to vaporize.

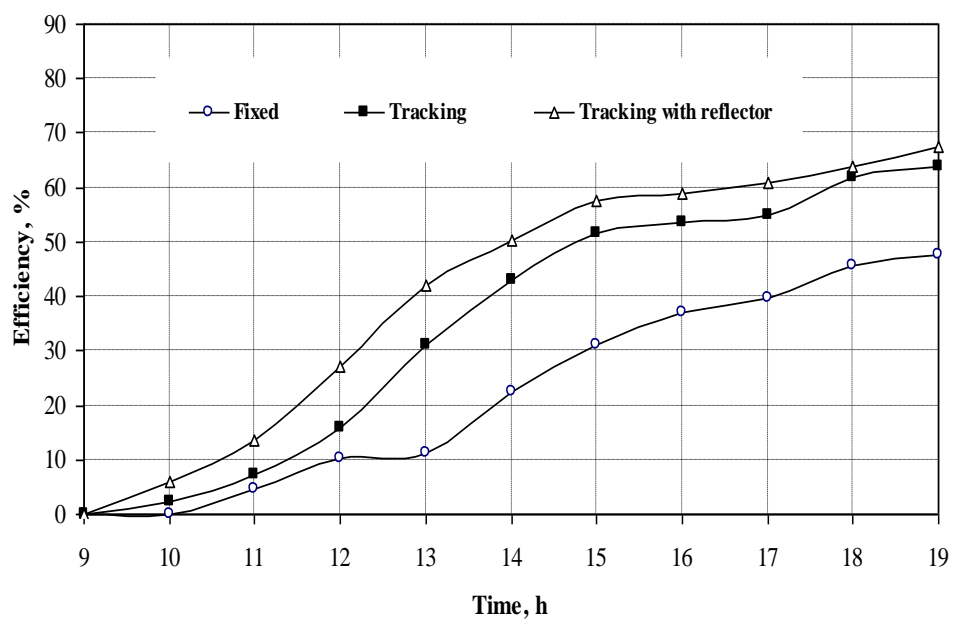

Fig. (8): Volumetric thermal efficiency for stationary non-tracking, tracking without reflector, and tracking with reflector as a function of solar time.

The effect of using sun tracking system on still productivity was clear in the production rate during four successive working days (Table 1). The tracking solar still with reflector achieved $129 \%$ and $81 \%$ more results in productivity than the stationary non-tracking solar still and tracking still without reflector, respectively. This due to the sun tracking solar still was continuously orientated in order to track the sun's rays from sunrise to sunset. Once each hour from sunrise to sunset the rays of the sun were almost perpendicular to the solar still which tracked the sun's rays. Consequently, the angle of incidence was at lower value at those times and the amount of available solar radiation was at its highest value. This phenomenon has been noticed by Tanaka and Nakatake (2006). They found that the solar energy absorption on the first partition as well as the distillate productivity of their proposed simple basin solar still can be significantly increased by rotating the solar still just once a day towards 
the sun. The angle of incidence for the stationary non-tracking solar still was only at lower value at solar noon, and it was greater that this value particularly in the early morning and later afternoon.

Table 1: Hourly average fresh water yield and volumetric efficiency for the three different configurations of solar still

\begin{tabular}{lcc}
\hline Mode & $\begin{array}{c}\text { Productivity, } \\
\mathbf{L}^{\mathbf{2}} \mathbf{~} \mathbf{h}\end{array}$ & $\begin{array}{c}\text { Volumetric } \\
\text { efficiency, } \\
\mathbf{\%}\end{array}$ \\
\hline Stationary non-tracking & 0.182 & 22.68 \\
Tracking without reflector & 0.330 & 35.08 \\
Tracking with reflector & 0.417 & 40.70 \\
\hline
\end{tabular}

\section{CONCLUSION}

In this present research work, several conclusions can be obtained and drawn as follows:

1- The tracking solar still with reflector results in an increasing the productivity by $129 \%$ and $81 \%$ as compared with stationary nontracking and tracking solar still without reflector, respectively.

2- The solar intensity for the tracking with reflector was higher than that of the stationary non-tracking and tracking without reflector for most of the time.

3- The saline water temperature was $35.5,36.0$, and $36.3^{\circ} \mathrm{C}$ in the early morning, and increasing to reach up to $67.1,73.9$, and $79.9^{\circ} \mathrm{C}$ afternoon for stationary non-tracking, tracking without reflector and tracking with reflector, respectively.

4- The productivity of fresh water increases until it reaches its maximum value at 15:00 $\mathrm{h}$. The maximum productivity recorded was 390, 700 and $860 \mathrm{ml}$ for stationary non-tracking, tracking without reflector and tracking with reflector, respectively.

5- The volumetric thermal efficiency increases with time until reaching the maximum value in the later afternoon. 
PROCESS ENGINEERING

\section{REFERENCES}

Abdallah, S. and Badran, O. O. (2008) "Sun tracking system for productivity enhancement of solar still" Desalination, 220: 669676.

Agha, K. R. (2009) "The thermal characteristics and economic analysis of a solar pond coupled low temperature multi-stage desalination plant" Solar Energy, 83: 501-510

Al-Hayek, I. and Badran, O. O. (2004) "The effect of using different designs of solar stills on water distillation" Desalination, 169: 121127

Arjunan, T. V. ; Aybar, H. S. ; and Nedunchezhian, N. (2009) " Status of solar desalination in India" Renewable and Sustainable Energy Review, 13: 2408-2418

ASHRAE, (2005) "Handbook of Fundamentals" American Society of Heating, Refrigerating and Air Conditioning Engineers, New York, USA

Darwish, M. A. ; and Alsairafi, A. (2004) "Technical comparison between TVC/MEB and MSF" Desalination, 170: 223-239

Duffie, J. A. and Beckman, W. A. (2006): "Solar Engineering of Thermal Processes" New York, N.Y., John Wiley and Sons.

El-Bahi, A. and Inan, D. (1999) "Analysis of a parallel double glass solar still with separate condenser" Renewable Energy, 17: 509521.

El-Swify, M. E. and Metias, M. Z. (2002) "Performance of double exposure solar still" Renewable energy, 26: 531-547

Goosen, M. F. A.; Sablani, S. S.; Shayya, W. H.; Paton, C. and AlHinai, H. (2000) "Thermodynamic and economic considerations in solar desalination" Desalination, 129: 63-89 
Ibrahim, S. M. A. (1996) "The forced circulation performance of a sun tracking parabolic concentrator collector" Renewable Energy, 9: $568-571$

Kalogirou, S. A. (1997) "Design and construction of a one-axis suntracking system" Solar Energy, 57(6): 465-469.

Kalogirou, S. M. (2005) "Seawater desalination using renewable energy sources" Progress in Energy and Combustion Science, 31: 242-281

Khalifa, A. N. and Al-Mutwalli, S. S. (1998) "Effect of two-axis sun tracking on the performance of compound parabolic concentrators" Ener. Convers. Manag., 39 (10): 1073-1079.

Li, C.; Goswami, Y.; and Stefanakos, E. (2013) "Solar assisted seawater desalination: A review" Renewable and Sustainable Energy Reviews, 19: 136-163

Micale, G.; Rizzuti, L.; and Cipollina, A. (2009) "Seawater desalination conventional and renewable energy processes" Springer link.

Mujahid, A. M.; and Alamoud, A. R. M. (1988) "An easily designed and constructed photovoltaic pyrheliometer" Solar \&Wind Technology, 5 2: 127-130

Murugavel, K. K.; Chockalingam, Kn. K. S. K.; and Srithar, K. (2008) "Progresses in improving the effectiveness of the single basin passive solar still" Desalination, 220: 677-686

Tamimi, A. (1987) "Performance of a solar still with reflectors and black dye" Int. J. Solar Energy, 5:229-235.

Tanaka, H.; and Nakatake, Y. (2006) "Theoretical analysis of a basin type solar still with internal and external reflectors" Desalination, 186: 280-299.

Tiwari, G. N.; Singh, H. N.; Tripathi, R. (2003) "Present status of solar desalination" Solar Energy, 75: 367-373 


\section{الملخص العربي}

\section{تأثير ملاحقة وحدة تقطير شمسي ذات عاكس خارجي لأشعة الشمس على

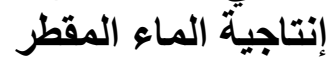

\section{إسلام حسن الشيخ}

أجري هذا البحث بقسم الهندسـة الزر اعيـة ـ كليـة الزر اعـة ـ جامعة قنـاة السويس ويهدف إلـي امكانية زيادة انتاجية وحدة تقطير شمسي ذات الميل من جانب واحد عن طريت نركيب عـاكس

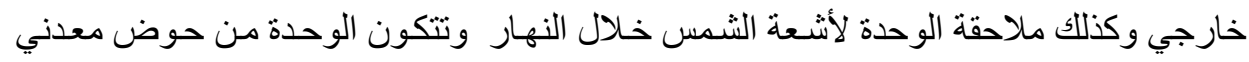

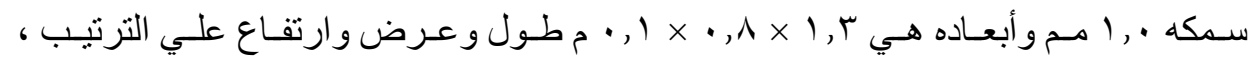

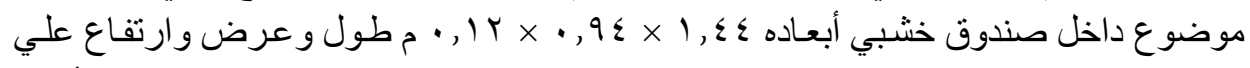

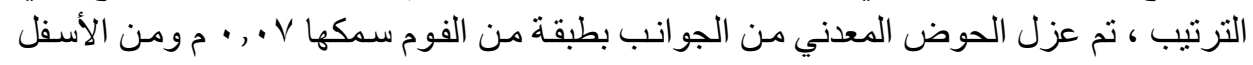

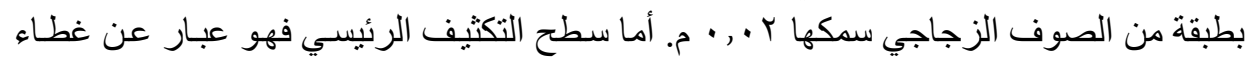

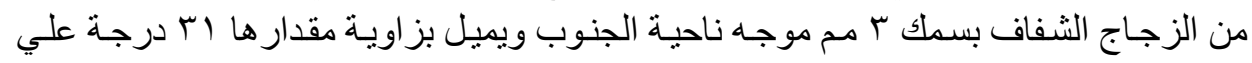
الأفقي للسماح للقطر ات المتكاتفة بالسريان إلي قناة التجميع الموجودة أسفل الغطـاء مـن الناحيـة

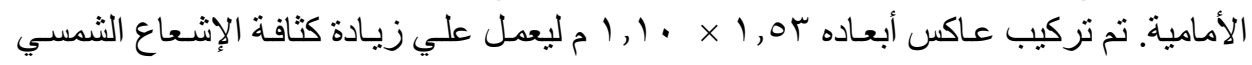

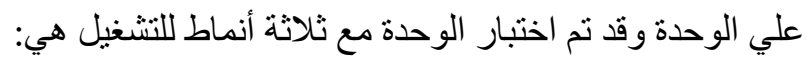

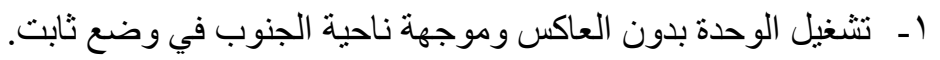

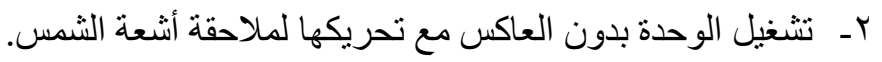

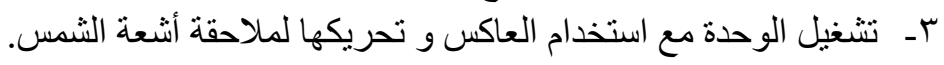

وقد أوضحت النتائج ما يلي:

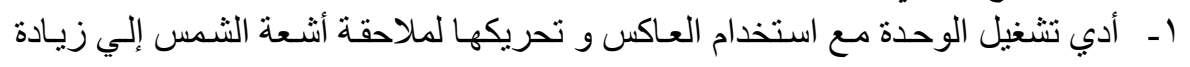

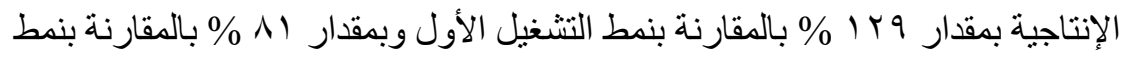
ז - كثافة الإشعاع الثشمسي في حالة نمط التشغيل الأول أكبر مما هو عليه في نمط التشـيل الأول و الثاني

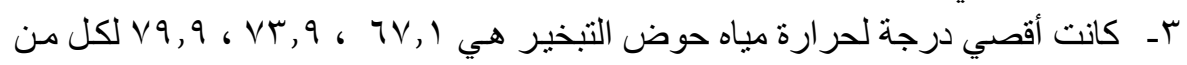

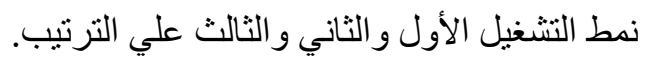
ع- تزداد الإنتاجية تدريجيا خلال اليوم حتي تصـل أقصـاها السـاعة الثالثة بعد الظهرحيث

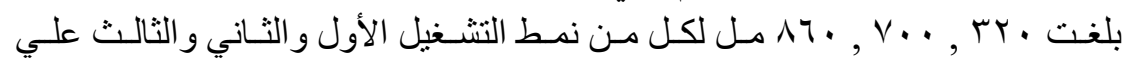
الترنيب.

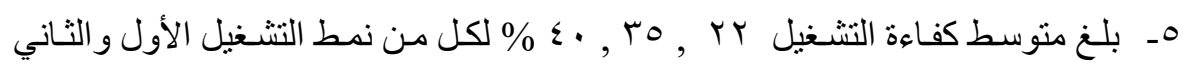
و الثالث علي الترتيب.

"أستاذ مساعد ـ قسم الهندسة الزراعية ـ كلية الزراعة ـ جامعة قناة السويس. 